\title{
Re-Assembly of Archaeological Massive Limestones Using Epoxy Resin Modified with Nanomaterials-Part 1: Experimental
}

\author{
Mohammad A. Aldosari1 ${ }^{*}$, Sawsan S. Darwish ${ }^{2}$, Mahmoud A. Adam², Nagib A. Elmarzugi ${ }^{3}$, \\ Sayed M. Ahmed ${ }^{4}$ \\ ${ }^{1}$ National Nanotechnology Research Center, King Abdulaziz City for Science and Technology (KACST), Riyadh, KSA \\ ${ }^{2}$ Department of Conservation, Faculty of Archaeology, Cairo University, Giza, Egypt \\ ${ }^{3}$ Tripoli University and National Nanotechnology Project, Biotechnology Research Center, Faculty of Pharmacy, LARST, \\ Tripoli, Libya \\ ${ }^{4}$ Ministry of Antiquities, The Grand Egyptian Museum, Giza, Egypt \\ Email: *aldosari@kacst.edu.sa, hafezm762000@yahoo.com, sawsansd@hotmail.com, nelmarzugi@gmail.com, \\ sayedmansour32@yahoo.com
}

How to cite this paper: Aldosari, M.A., Darwish, S.S., Adam, M.A., Elmarzugi, N.A. and Ahmed, S.M. (2020) Re-Assembly of Archaeological Massive Limestones Using Epoxy Resin Modified with Nanomaterials-Part 1: Experimental. Green and Sustainable Chemistry, 10, 24-38.

https://doi.org/10.4236/gsc.2020.101003

Received: December 12, 2019

Accepted: February 17, 2020

Published: February 20, 2020

Copyright (c) 2020 by author(s) and Scientific Research Publishing Inc. This work is licensed under the Creative Commons Attribution International License (CC BY 4.0).

http://creativecommons.org/licenses/by/4.0/

\section{(c) (i) Open Access}

\begin{abstract}
Massive limestones were used in construction of ancient Egyptian tombs, temples, obelisks and other sculptures. These stones are always exposed to physico-mechanical deterioration and destructive forces, leading to partial or total collapse. The task of reassembling this type of artifacts represents a big challenge for the conservators. Recently, the researchers are turning to new technologies to improve the properties of traditional adhesive materials and techniques used in re-assembly of broken massive stones. The epoxy resins are used extensively in stone conservation and re-assembly of broken stones because of their outstanding mechanical properties. The adding of nanoparticles to polymeric adhesives at low percentages may lead to substantial improvements of their mechanical performances in structural joints and massive objects. The aim of this study is to evaluate the effectiveness of montmorillonite clay, calcium carbonate, and silicon dioxide nanoparticles for enhancing the performances of epoxy adhesives used in re-assembly of archaeological massive limestones. Scanning electron microscopy (SEM) was employed in order to investigate the morphology of the prepared nanocomposites, and the distribution of nanoparticles inside the composites. Artificial aging, tensile, compressive, and elongation strength tests were used to evaluate the efficiency of epoxy-nanocomposites. The results showed that the epoxy-clay nanocomposites exhibited superior tensile, compressive, and elongation strength, in addition to improving the mechanical properties of stone joints.
\end{abstract}




\section{Keywords}

Epoxy Resins, Nanocomposites, Re-Assembly, Massive Limestones, Mechanical Properties

\section{Introduction}

Large stone carvings were use in the construction and construction of many historical Pharaonic buildings such as (tombs, temples, obelisks, etc.) [1], which became with the passage of time subject to deterioration and physical-mechanical change of the forces of these stone carvings, which in turn led to a change in their structures and mechanical propertiesand thus their collapse and breakage [2]. Conservation and reassembly of such types of large objects are particularly challenging because of the uncontrollable size and heavy weight. Epoxy resins were discovered in 1909 by Prileschajew; the practical development began in the late 1930s. By the 1950s, these resins were widely used commercially [3]. Because of their excellent mechanical properties, high adhesion strength, and good heat and chemical resistances, currently epoxy resins have been widely used for high-performance coatings, electronic materials, adhesives, and matrices for fiber-reinforced composites, and encapsulating materials [4] [5]. From as early as the 1960s, when the use of polymers for consolidation of decayed stone came into vogue, epoxy resins were candidates of high interest as stone adhesive materials, consolidates, and gap-fillers because of their durability, good adhesion, and exceptional mechanical strength [6]. However, it soon became apparent that there were advantages as well as disadvantages to the use of the epoxy resins in stone conservation. The failure of some of these treatments was due to their irreversibility; the high concentration of resin near the surface inevitably left a crust and caused color problems. Sometimes, epoxies are unable to penetrate well in a stone block and caused darkening and other color problems [7] [8]. In theory and in accordance with the principles of conservation science and the shortcomings mentioned, so as a general rule, epoxy resins should be avoided [9]. However, there are many views that emphasize the need to use epoxy in some cases of stone conservation, especially in cases of re-assembly of massive broken stones, where epoxies are occasionally required because nothing else has the necessary strength; they are excellent when a very strong, permanent bond is required [10] [11]. Although some opinions object to its use in conservation, but conservation experts always confirm that the high mechanical properties of epoxies are the reason that epoxy resins reinforced with other materials such as stainless steel and titanium bars are usually the appropriate materials for re-assembly and reconstructions of massive stone artifacts [12].

The mentioned problems and drawbacks in epoxy materials have attracted significant academic and industrial interest to increase the efficacy of the conventional methods to achieve higher adhesive and protection efficiency [13]. The properties of adhesives can be modified by adding several compounds; Conven- 
tional compounds sometimes modify some properties of the adhesives at expense of the other properties. Meanwhile the extent of improvements achieved by conventional compounds is limited in some cases [14]. Recently, introduction of nanotechnology has opened an opportunity for adhesive industry to develop a new generation of adhesives, and recent developments in fillers and reinforcements technology have made it possible to enhance the properties and applications of polymeric materials. [15] [16]. These substances have attracted interest in engineering and conservation science due to their distinctive properties, such as high-dimensional stability, optical clarity, flame retardancy and distinguished mechanical properties [17]. The nanoparticles can be dispersed within the epoxy resin matrix to form an epoxy nanocomposite as benign solutions to enhance the durability of epoxy resin [18]. Nanoparticles can also prevent epoxy disaggregation during curing, resulting in more homogenous coatings. Nanoparticles tend to occupy small hole defects formed from local shrinkage during curing of the epoxy resin and act as a bridge interconnecting more molecules. This results in a reduced total free volume as well as an increase in the cross-linking density [19]. Montmorillonite clay, $\mathrm{CaCO}_{3}$ and $\mathrm{SiO}_{2}$ /epoxy nanocomposites are new class of composite materials, in which nanoparticles are dispersed in a polymer matrix offer new possibilities for the epoxies as adhesive materials used in reassembly and conservation of archaeological massive stones [20] [21]. The selection of these materials was based on their high physical, chemical, and mechanical properties. Montmorillonite (MMT) clay nanoparticles were chosen for their distinctive properties [22], in addition to that it consists of layered silicates which can be inserted individually in nanosize by polymer chains, its high aspect ratio, and low cost [23]. Nanoscale dispersion of the layered silicate into a polymer resin can exhibit dramatic improvements in mechanical and thermal properties at low clay contents because of the strong synergistic effects between the polymer and the silicate platelets in both the molecular and nanometric scales [24]. Calcium carbonate $\left(\mathrm{CaCO}_{3}\right)$ is one of the most commonly used inorganic fillers in polymer [25]. It has attracted much research interest because of their low-cost, availability, and its long history of application in various fields. The addition of $\mathrm{CaCO}_{3}$ nanoparticles showed improving in the thermal and mechanical properties of polymer matrix and hence increasing the ductility and impact strength of composites [26] [27]. Silica nanoparticles have attracted wide interest in view of their distinguished optical, electrical and thermal properties [28], it has been applied in many fields, and was found that mixing of the untreated fumed silica nanoparticles with polymeric materials can bring mechanical improvement, and may be used to achieve an enhancement of the hydrophobicity [29] [30].

The current study divided into two parts: Part 1: The experimental study. This part is designed to evaluate the effectiveness of the above mentioned nanoparticles in improving the properties of epoxy resins used in conservation of massive stone artifacts. The study aims to investigate the efficiency of selected nanocomposites in re-assembly of massive archaeological stones and identify 
the best of these nanocomposites for dealing with such types of stone monuments.

The obtained nanocomposites were prepared using mechanical methods, and characterized using Scanning electron microscopy (SEM) to evaluate the surface morphology and the homogeneous distribution of filler nanoparticles in the polymer matrix. The obtained epoxy-nanocomposites were casted in form of epoxy molds, and were applied as adhesive material for experimental stone samples. The behavior of the nanocomposites exposed to artificial aging was investigated. The mechanical properties were determined for both the epoxy molds and experimental stone samples with and without artificial aging.

Part 2: The applied study. This part will be a continuation of the experimental study that were carried out in part 1, the applied study represents a big project was carried out on 3 archaeological massive stones discovered separately in Ain Shams (Heliopolis) archaeological area (see Figure 1). The study aims to apply the best nanocomposites, depending on the experimental results in part 1, as adhesive materials for reassembly of those 3 archaeological massive stones.

\section{Experimental}

\subsection{Chemicals}

The epoxy resin used as a matrix was PY 1092-1 (100 part by weight) and its hardener HY 1092 (45 part by weight). It was purchased from (Huntsman Advanced Materials Ltd, Basel, Switzerland), commercially known as Araldite ${ }^{\oplus}$ Precision. The weight ratio of the epoxy resin to the hardener was 2:1.

The montmorillonite Organo-modified Nano clay (cloisite 30B), $\mathrm{CaCO}_{3} \mathrm{Nano}$ powder (NPCC 201), and $\mathrm{SiO}_{2}$ nanoparticles (S-type, Spherical, Nonporous, and amorphous) with particle diameter average $<50 \mathrm{~nm}$, were produced and characterized by Nanografi Nanoteknoloji company-Ankara, Turkey and the data sheet supplied by the company provided with all information about the nanomaterials properties and size.

\subsection{Materials}

\section{Preparation of Experimental Limestone Samples}

The experimental limestone blocks (samples) were collected from the quarry of Helwan plateau in the south part of greater Cairo, one of the most important limestone quarries in Egypt. Ain Shams, Heliopolis, and Mataria monuments were constructed mainly from Helwan and Abu Zaabl local limestone quarries. Experimental limestone blocks were cut into rectangular samples $(10 \mathrm{~cm} \times 2 \mathrm{~cm}$ $\times 2 \mathrm{~cm}$ ) for carrying the mechanical tests such as Tensile and elongation strength tests. The used limestone samples were compatible with the chemical composition of the original material of studied archeological limestone blocks (Part 2). Afterwards, the samples were prepared for applying the studied nanocomposites adhesives by cleaning the surface by soft brush, then washed using distilled water, and dried in an oven at $105^{\circ} \mathrm{C}[31]$. 


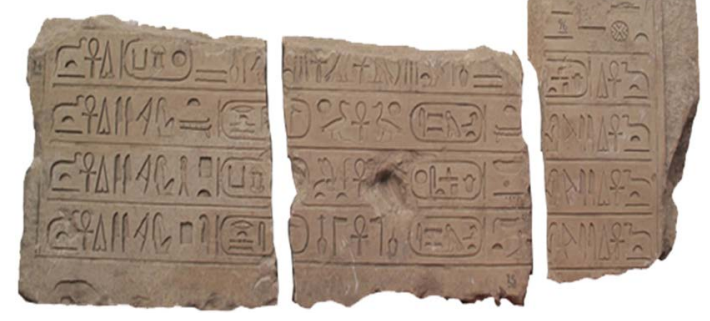

Figure 1. Shows the three archaeological massive stones that were discovered separately in Ain Shams (Heliopolis) archaeological area.

\subsection{Methodologies}

\subsubsection{Nanocomposites Preparation}

There are many methods to prepare polymer-nanocomposites whether chemical or mechanical methods. However, according to the properties of epoxy resin and its high viscosity, the mechanical method was most suitable mixing epoxy resin with nanoparticles in order to form intercalated nanocomposite ensures the distribution of nanoparticles within the epoxy resin evenly and uniformly. In this regard, Epoxy nanocomposites are usually prepared by dispersing nanoparticles (Clay, $\mathrm{CaCO}_{3}$, and $\mathrm{SiO}_{2}$ ) into the epoxy matrix without hardener and the epoxy resin were mixed with nanoparticles content $3 \%(\mathrm{w} / \mathrm{v})$, and mixed well with a glass rod before subjected to mechanical stirring at $500 \mathrm{rpm}$ for $1 \mathrm{~h}$. Then, the mixture was held at $70^{\circ} \mathrm{C}-80^{\circ} \mathrm{C}$ and stirred again at $2500 \mathrm{rpm}$ for $1 \mathrm{~h}$ with a high-shear mixer. The mixed compositions were mechanically blended and sonicated for $2 \mathrm{~h}$ with a little heating to ensure the distribution of nanoparticles within the epoxy matrix with no clustering or agglomeration of nanoparticles [32] [33].

\subsubsection{Scanning Electron Microscopy (SEM)}

The surface morphology and fracture surface of the obtained epoxy nanocomposites were investigated using SEM in order to investigate if filler nanoparticles were distributed homogenously and do not form aggregates in the epoxy polymer matrix (The SEM investigation were carried out in FEG Lab; the Egyptian mineral resources authority, Cairo, Egypt).

\subsubsection{Preparation and Casting of Epoxy-Nanocomposites Molds}

After preparing the epoxy nanocomposites, the appropriate amount of hardener according to the above-mentioned mixing ratio $(2: 1)$ was added and mixed well. Afterwards, the obtained compositions (Resin, hardener, and nanoparticles) were casted in mold with special frame made from steel with dimensions $(10 \mathrm{~cm}$ $\times 2 \mathrm{~cm} \times 1 \mathrm{~cm})$ and $(2 \mathrm{~cm} \times 2 \mathrm{~cm} \times 1 \mathrm{~cm})$, and were left to dry for $24 \mathrm{~h}$ to be ready for carrying the mechanical evaluation tests (See Figure 2).

\subsubsection{Assembly of Experimental Limestone Samples Using Adhesive Epoxy-Nanocomposites}

The obtained adhesive nanocomposites (Resin, hardener, and nanoparticles) 
were applied as adhesive materials to assembly of experimental limestone samples by joining each two samples together at room pressure and temperature. The joined samples were left to dry for $24 \mathrm{~h}$ at room temperature with controlled RH 50\%, the time set for epoxy nanocomposites to achieve full dryness (See Figure 3 ). Then, the joined samples underwent laboratory procedures and artificial aging with the aim of assessing the mechanical properties of adhesive materials.
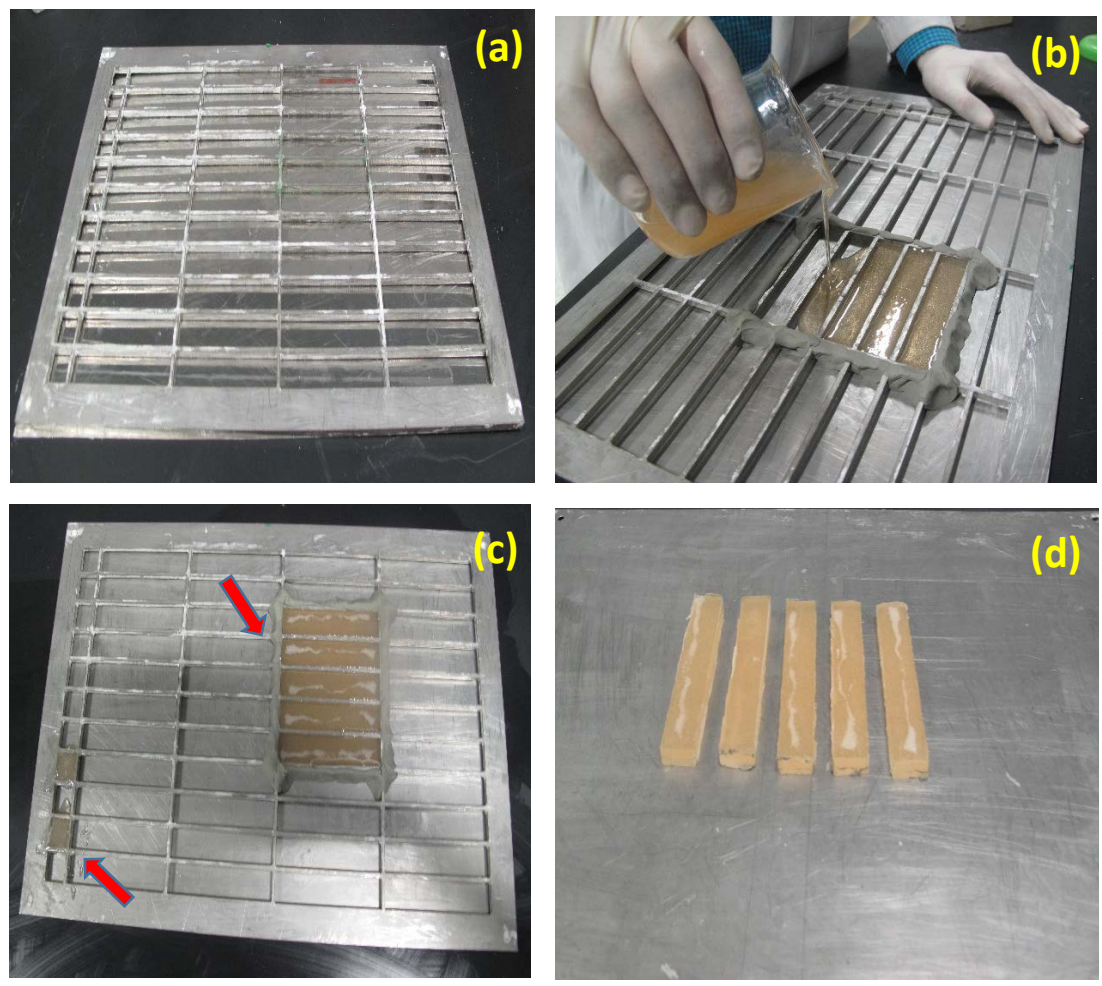

Figure 2. Shows the stages of preparation and casting of epoxy-nanocomposites molds. (a) The prepared steel mold for casting, and (b) During casting of nanocomposites, and (c) After casting and during drying, and (d) The epoxy-nanocomposites molds after drying and extract the samples from the casting mold.
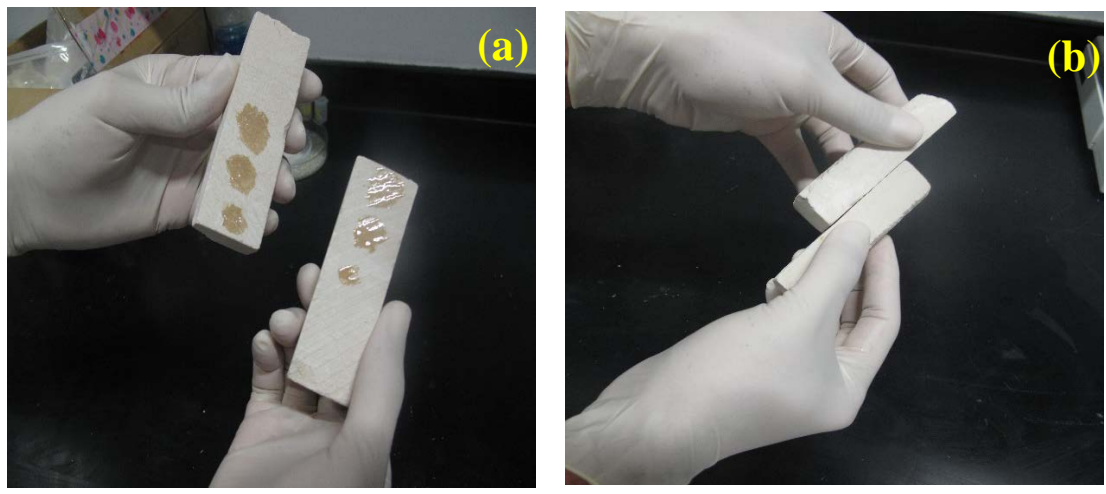

Figure 3. Shows the stages of assembly of experimental limestone samples using adhesive epoxy-nanocomposites (a) Application of adhesive material, and (b) Joining each two experimental samples together. 


\subsubsection{Artificial Aging}

Epoxy molds samples and assembly experimental limestone samples were subjected to artificial aging tests, with aim of simulating the actual environmental deteriorating conditions and at quantifying the durability of the adhesive materials. Two types of weathering cycles were performed as follow:

\section{1) Salt crystallization weathering}

The experimental samples were subjected to ten cycles of immersion in a saturated $\mathrm{Na}_{2} \mathrm{SO}_{4}$ solution for $4 \mathrm{~h}$ followed by $28 \mathrm{~h}$ of exposure to air in normal room conditions $\left(25^{\circ} \mathrm{C}\right.$ and $40 \%$ R.H.) then $16 \mathrm{~h}$ in an oven at $70^{\circ} \mathrm{C}$ [34].

\section{2) Wet-dry cycles}

This test was carried out with the aim of evaluating the stability of the adhesive materials against thermal effects. The test consists of 40 cycles of immersion and drying as follows: $16 \mathrm{~h}$ of total immersion in distilled water then $8 \mathrm{~h}$ in an oven at $70^{\circ} \mathrm{C}[35]$.

\subsubsection{Mechanical Properties}

The mechanical properties of tested nanocomposites adhesives were conducted for both epoxy molds samples, and assembly experimental limestone samples, before and after artificial aging to evaluate its long-term durability against different mechanical forces. Therefore, three types of mechanical tests mentioned below were conducted.

\section{1) Tensile and elongation strength measurement}

Tensile and elongation strength were measured according to ASTM D 412-66 using an electronic tensile testing machine (Zwick 1425). Tensile test was performed at a crosshead speed of $10 \mathrm{~mm} / \mathrm{min}$, and was calculated by using the following equation: Tensile strength $(\mathrm{TS})=(\mathrm{F} / \mathrm{tw}) \mathrm{MPa}$, where $\mathrm{F}=$ load applied to rupture, $\mathrm{t}=$ the thickness of the specimen and $\mathrm{w}=$ width of the specimen. At the break, the elongation is expressed as the percent of the original benchmark length attained beyond rupture.

Ultimate elongation $\mathrm{E} \%=((\mathrm{L}-\mathrm{L} 0) / \mathrm{L} 0) 100$, Where: $\mathrm{L}=$ Length of the specimen at the moment of rupture and $\mathrm{L} 0=$ the length between bench marks [36] (The tests were performed in Housing and building national research center, Dokki, Giza, Egypt).

\section{2) Compressive strength measurement}

Compressive strength was performed on the epoxy molds samples using an Amsler compression-testing machine, with the load applied perpendicular to the bedding plane according to ASTM C 170 standard (1976). For each compound, 3 samples were tested, and the average values of compression strength were recorded [37].

\section{Results and Discussions}

\subsection{Effect of Nanoparticles on the Morphology of Epoxy RESIN}

SEM characterization methods were employed to investigate microstructure, morphology, and mixture process of the prepared epoxy-nanocomposites. SEM 
images of the control resin (pure epoxy, containing no nanoparticles) and the epoxy nanocomposites are shown in (Figures 4(a)-(d)). SEM image in (Figure 4(a)) indicates that, the pure epoxy resin has a relatively homogeneous morphology with high ratio of purity. The SEM images of the epoxy resin modified by used nanoparticles in (Figures 4 (b)-(d)) demonstrate that an intercalated nanocomposite has been formed by ultrasonic dispersion, and the nanoparticles was distributed well within the epoxy resin evenly and uniformly with no clustering or agglomeration. After adding nanoparticles into epoxy matrix, the obtained mixture was observed to be much denser than the pure epoxy, but showed no sign of nanoparticle agglomeration, and kept its homogeneous morphology. In the case of the epoxy resin modified with montomorillite clay nanoparticles, the epoxy-clay nanocomposites exhibited a textural structure, no agglomeration and more denser than the pure epoxy, and the epoxy modified with $\mathrm{SiO}_{2}$ and $\mathrm{CaCO}_{3}$ nanoparticles, also it was clearly observed the silicate platelets dispersed in nanoscale size in a polymer matrix (marked with red arrows), as shown in Figure 4(b). In addition to that, the investigation results confirmed the previous studies on epoxy-nanocomposites [38] [39], and revealed that, the addition of small amount, by weigh of these nanoparticles not more than $3 \mathrm{wt} \%$ into epoxy matrix, will be more appropriate to mix and intercalated well with high viscosity of epoxy, and the finished products can be made lighter and more
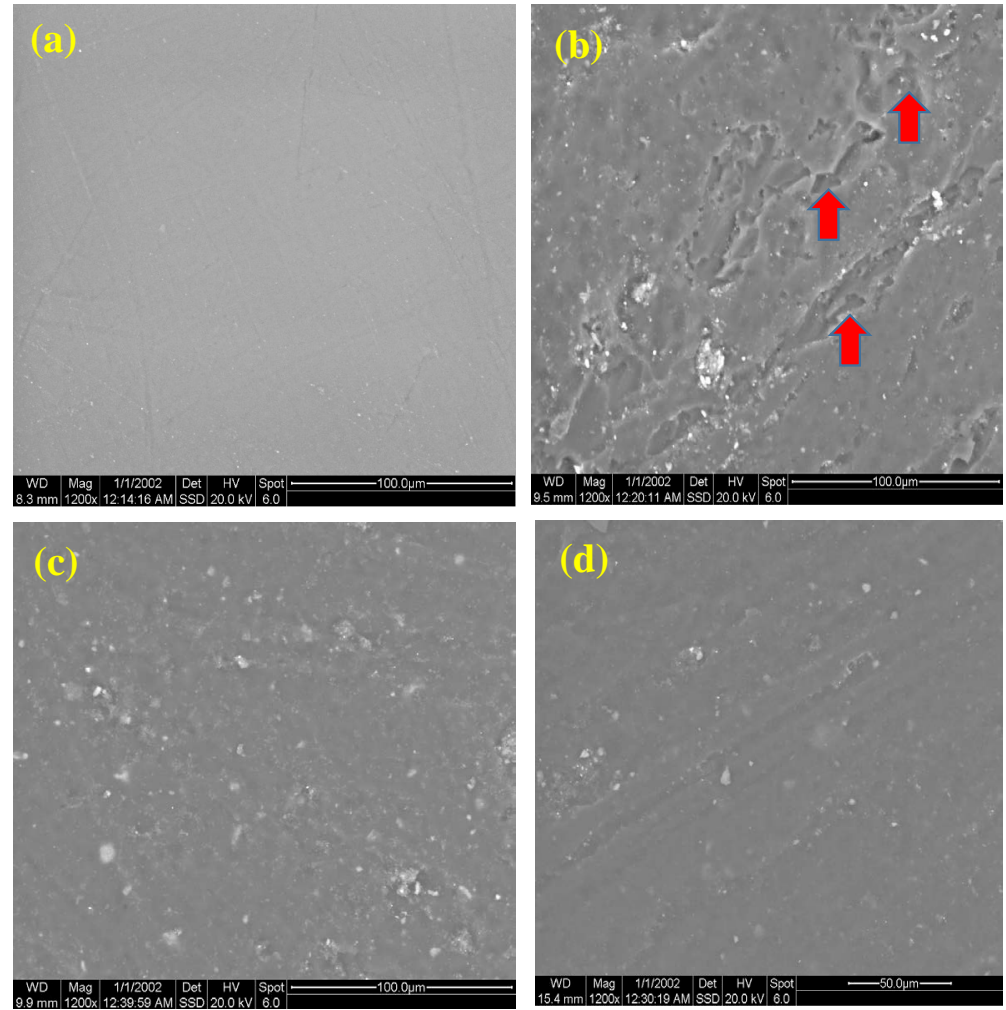

Figure 4. SEM micrographs $(1200 \times)$ of the prepared epoxy-nanocomposites after mixture process (a) shows the pure epoxy, and (b) epoxy with montomorillite clay nanoparticles, and (c) epoxy with $\mathrm{CaCO}_{3}$ nanoparticles, and (d) epoxy with $\mathrm{SiO}_{2}$ nanoparticles. 
transparent compared to traditionally filled composites. Epoxy-nanocomposites with high content of nanoparticles can induce nanoparticles agglomeration, and more difficultly in the procedures of mixing and applying [40]. However, these advantages can only be exploited if filler nanoparticles are distributed homogenously and do not form aggregates in the polymer matrix. Particle aggregation, which is often detected in particulate filled polymers can result in a number of problems, including deteriorated mechanical properties and poor aesthetics. The small size of the added nanoparticles is also advantageous and plays an effective role in the final product, since it enables their penetration into ultra-small holes, indentation and capillary areas both in the polymer matrix itself and at the stone substrate [41].

\subsection{Mechanical Properties}

\subsubsection{Effect of Nanoparticles on the Compressive Strength Properties of Epoxy-Nanocomposites}

Measurement of compressive strength was performed on all of casted epoxy molds samples, whether the pure epoxy and epoxy-nanocomposites before and after artificial aging. The test was performed based on the ASTM C 170 standard in order to investigate the effect of adding different nanoparticles on the mechanical performance of epoxy-nanocomposites. For each compound, at least 3 samples were tested and the mean values were considered. The compressive strength tests results of various nanocomposites are indicated in Table 1. By comparison, the results revealed that, addition of $3 \%(\mathrm{w} / \mathrm{v})$ of nanoparticles to a polymer matrix can easily improve the mechanical properties of the epoxy adhesives with significant and acceptable ratio from the conservation point of view, and able to enhance the durability of epoxy resin used in assembly of massive stone objects. The obtained measurements indicated that, the results of clay nanoparticles gave the highest values of compressive strength before and after subject to artificial aging when compared with those of pure epoxy sample and epoxy mixed with $\mathrm{CaCO}_{3}$ and $\mathrm{SiO}_{2}$. The montomorillite clay nanoparticle was the most effective filler in the improvement of epoxy matrix, this is maybe attributed to the formation of exfoliated structure for epoxy nanocomposites with $3 \%(\mathrm{w} / \mathrm{v})$ of clay. In the exfoliated structure, individually silicate layers in nanometer size are dispersed uniformly in the polymer matrix with high aspect ratio. In addition, the large numbers of reinforcing nanoclay platelets presented in the polymer matrix act as efficient stress transfer agents in the nanocomposites, inducing plastic deformation into the base polymer, and finally increase the compressive strength.

The results also showed significant effectiveness of the modified $\mathrm{CaCO}_{3}$ nanoparticles as a filler material for the epoxy composites, which comes in second class after clay nanoparticles. The results confirm the reinforcement effect of calcium carbonate nanoparticles in epoxy matrix, when incorporated in low contents due to their high surface contact area which is a result of the small particle diameter, also the strong interaction between the polymer and filler, be- 
cause of the large interfacial area between them. Addition of rigid particles to a polymer matrix can easily improve the polymer properties since the rigidity of inorganic fillers is generally much higher than that of organic polymers.

\subsubsection{Effect of Nanoparticles on the Tensile and Elongation Strength Properties}

Tests of tensile and elongation strength were measured according to ASTM D 412-66 standard. The measurements of tensile strength were performed on both of casted epoxy molds samples and assembly of experimental limestone samples before and after artificial aging. For each compound, at least 3 samples were tested and the mean values were considered. From the tensile test, results of neat epoxy and its nanocomposites as presented in Table 2 and Table 3. The obtained values confirmed the results of compressive strength test; it was observed that the Clay/epoxy nanocomposites gave the highest values of tensile strength after treatment and artificial aging when compared with that of pure epoxy sample and epoxy mixed with other nanoparticles. The chemical composition of clay, as layered silicates, nanosized-layer-filled polymers can exhibit dramatic improvements in thermal, physical, and mechanical properties at low montomorillite clay contents, because of the strong synergistic effects between polymer and the silicate platelets on both the molecular and nanometric scales as previously mentioned. The elongation strength test was performed on casted epoxy molds samples before and after artificial aging, and the results also showed the effective role of montomorillite clay nanoparticle on epoxy matrix. In summary, the values showed that the modified montomorillite clay, followed by the modified $\mathrm{CaCO}_{3}$ nanoparticles can effectively improve the mechanical properties of epoxy resin, with significant and acceptable ratio from the conservation point of view, enhancing the durability of epoxy resin as adhesive materials used in assembly of broken massive stone monuments. The elongation test results of various compounds of epoxy/nano-composites are indicated in Table 4.

Table 1. Variance rates in compressive strength of studied epoxy-nanocomposites samples before and after artificial aging.

\begin{tabular}{|c|c|c|c|c|c|c|}
\hline \multirow{3}{*}{ Samples } & \multicolumn{6}{|c|}{ Compressive Strength of Epoxy-Nanocomposites Samples } \\
\hline & \multicolumn{2}{|c|}{$\begin{array}{c}\text { Before Artificial } \\
\text { Aging }\end{array}$} & \multicolumn{2}{|c|}{$\begin{array}{l}\text { After Artificial } \\
\text { Thermal Aging }\end{array}$} & \multicolumn{2}{|c|}{$\begin{array}{l}\text { After Artificial } \\
\text { Salt Weathering }\end{array}$} \\
\hline & $\begin{array}{c}\text { Average Value } \\
\left(\mathrm{kg} / \mathrm{cm}^{2}\right)\end{array}$ & $\begin{array}{c}\text { Change } \\
\%\end{array}$ & $\begin{array}{l}\text { Average Value } \\
\left(\mathrm{kg} / \mathrm{cm}^{2}\right)\end{array}$ & $\begin{array}{c}\text { Change } \\
\%\end{array}$ & $\begin{array}{c}\text { Average Value } \\
\left(\mathrm{kg} / \mathrm{cm}^{2}\right)\end{array}$ & $\begin{array}{c}\text { Change } \\
\%\end{array}$ \\
\hline Pure epoxy & 125.53 & 0.00 & 120.60 & -3.92 & 124.11 & -1.13 \\
\hline $\begin{array}{c}\text { Clay/epoxy } \\
\text { nanocomposites }\end{array}$ & 133.89 & +6.65 & 131.22 & -1.99 & 133.11 & -0.58 \\
\hline $\begin{array}{c}\mathrm{CaCO}_{3} / \text { epoxy } \\
\text { nanocomposites }\end{array}$ & 129.84 & +3.43 & 126.84 & -2.31 & 128.98 & -0.66 \\
\hline $\begin{array}{c}\mathrm{SiO}_{2} / \text { epoxy } \\
\text { nanocomposites }\end{array}$ & 127.80 & +1.80 & 123.40 & -3.44 & 126.88 & -0.71 \\
\hline
\end{tabular}


Table 2. Variance rates in tensile strength of studied epoxy-nanocomposites samples before and after artificial aging.

\begin{tabular}{ccccccc}
\hline & \multicolumn{5}{c}{ Tensile Strength of Epoxy-Nanocomposites Samples } \\
\cline { 2 - 7 } Samples & \multicolumn{3}{c}{$\begin{array}{c}\text { Before } \\
\text { Artificial Aging }\end{array}$} & $\begin{array}{c}\text { After Artificial } \\
\text { Thermal Aging }\end{array}$ & \multicolumn{2}{c}{$\begin{array}{c}\text { After Artificial } \\
\text { Salt Weathering }\end{array}$} \\
\cline { 2 - 7 } & $\begin{array}{c}\text { Average Value } \\
\text { (Mpa/TS) }\end{array}$ & $\begin{array}{c}\text { Change } \\
\%\end{array}$ & $\begin{array}{c}\text { Average Value } \\
\text { (Mpa/TS) }\end{array}$ & $\begin{array}{c}\text { Change } \\
\text { Average Value }\end{array}$ & $\begin{array}{c}\text { Change } \\
\text { (Mpa/TS) }\end{array}$ & $\%$ \\
\hline $\begin{array}{c}\text { Pure epoxy } \\
\text { Clay/epoxy }\end{array}$ & $19.59^{*}$ & 0.00 & 17.66 & -9.85 & 18.11 & -7.55 \\
$\begin{array}{c}\text { nanocomposites } \\
\text { CaCO } / \text { epoxy }\end{array}$ & 28.53 & +45.63 & 27.60 & -3.25 & 28.22 & -1.08 \\
$\begin{array}{c}\text { nanocomposites } \\
\mathrm{SiO}_{2} / \text { epoxy }\end{array}$ & 25.56 & +30.47 & 23.27 & -8.95 & 24.06 & -5.86 \\
nanocomposites & 210.47 & +9.59 & 29.21 & -10.52 & 20.01 & -6.80 \\
\hline
\end{tabular}

Table 3. Variance rates in tensile strength of of assembly stone samples before and after artificial aging.

\begin{tabular}{|c|c|c|c|c|c|c|}
\hline \multirow{3}{*}{ Samples } & \multicolumn{6}{|c|}{ Tensile Strength of Assembly Stone Samples } \\
\hline & \multicolumn{2}{|c|}{$\begin{array}{c}\text { Before } \\
\text { Artificial Aging }\end{array}$} & \multicolumn{2}{|c|}{$\begin{array}{l}\text { After Artificial } \\
\text { Thermal Aging }\end{array}$} & \multicolumn{2}{|c|}{$\begin{array}{l}\text { After Artificial } \\
\text { Salt Weathering }\end{array}$} \\
\hline & $\begin{array}{c}\text { Average Value } \\
(\mathrm{Mpa} / \mathrm{TS})\end{array}$ & $\begin{array}{c}\text { Change } \\
\%\end{array}$ & $\begin{array}{c}\text { Average Value } \\
(\mathrm{Mpa} / \mathrm{TS})\end{array}$ & $\begin{array}{c}\text { Change } \\
\%\end{array}$ & $\begin{array}{c}\text { Average Value } \\
(\mathrm{Mpa} / \mathrm{TS})\end{array}$ & $\begin{array}{c}\text { Change } \\
\%\end{array}$ \\
\hline Pure epoxy & 33.66 & 0.00 & 31.13 & -7.50 & 32.01 & -4.90 \\
\hline $\begin{array}{c}\text { Clay/epoxy } \\
\text { nanocomposites }\end{array}$ & 42.76 & +27.03 & 41.50 & -2.94 & 42.10 & -1.54 \\
\hline $\begin{array}{c}\mathrm{CaCO}_{3} / \text { epoxy } \\
\text { nanocomposites }\end{array}$ & 38.89 & +15.53 & 36.88 & -5.16 & 37.88 & -2.59 \\
\hline $\begin{array}{c}\mathrm{SiO}_{2} / \text { epoxy } \\
\text { nanocomposites }\end{array}$ & 35.32 & +4.93 & 33.11 & -6.25 & 34.09 & -3.48 \\
\hline
\end{tabular}

Table 4. Variance rates in elongation strength of studied epoxy-nanocomposites samples before and after artificial aging.

\begin{tabular}{|c|c|c|c|c|c|c|}
\hline \multirow{3}{*}{ Samples } & \multicolumn{6}{|c|}{ Elongation Strength of Epoxy-Nanocomposites Samples } \\
\hline & \multicolumn{2}{|c|}{$\begin{array}{c}\text { Before } \\
\text { Artificial Aging }\end{array}$} & \multicolumn{2}{|c|}{$\begin{array}{l}\text { After Artificial } \\
\text { Thermal Aging }\end{array}$} & \multicolumn{2}{|c|}{$\begin{array}{l}\text { After Artificial } \\
\text { Salt Weathering }\end{array}$} \\
\hline & $\begin{array}{l}\text { Average } \\
\text { Value \% }\end{array}$ & $\begin{array}{c}\text { Change } \\
\%\end{array}$ & $\begin{array}{l}\text { Average } \\
\text { Value \% }\end{array}$ & $\begin{array}{c}\text { Change } \\
\%\end{array}$ & $\begin{array}{l}\text { Average } \\
\text { Value \% }\end{array}$ & $\begin{array}{c}\text { Change } \\
\%\end{array}$ \\
\hline Pure epoxy & 9.37 & 0.00 & 7.63 & -18.56 & 8.89 & -5.12 \\
\hline $\begin{array}{c}\text { Clay/epoxy } \\
\text { nanocomposites }\end{array}$ & 18.42 & +96.58 & 17.49 & -5.04 & 17.99 & -2.33 \\
\hline $\begin{array}{c}\mathrm{CaCO}_{3} / \text { epoxy } \\
\text { nanocomposites }\end{array}$ & 14.18 & +51.33 & 13.61 & -4.01 & 13.89 & -2.04 \\
\hline $\begin{array}{c}\mathrm{SiO}_{2} / \text { epoxy } \\
\text { nanocomposites }\end{array}$ & 11.61 & +23.90 & 10.23 & -11.88 & 10.76 & -7.32 \\
\hline
\end{tabular}

\section{Conclusion}

This study focused on reassembling archaeological massive limestones using epoxy resin (Araldite 1092) modified with nanomaterials. In this study, mont- 
morillonite clay, $\mathrm{CaCO}_{3}$, and $\mathrm{SiO}_{2}$ nanoparticles were added to epoxy resin in order to improve its physiochemical and mechanical properties and identify its ability to use in re-assembly of massive stone monuments. The study showed that the low content of nanoparticles (3\% w/v) is appropriate to mix and intercalated well with high viscosity of epoxy. The results obtained by mechanical tests (compressive, tensile, and elongation strength) indicated that clay nanoparticles were the best nanomaterial which filled the epoxy matrix, and gave the highest values of mechanical properties before and after artificial aging compared to pure epoxy sample and epoxy mixed with $\mathrm{CaCO}_{3}$ or $\mathrm{SiO}_{2}$, followed by $\mathrm{CaCO}_{3}$ nanomaterial. Therefore, the study recommends the use of epoxy-clay nanocomposite in the case of reassembly of archaeological massive limestones, which will be applied in part 2 of the study.

\section{Acknowledgements}

The authors would like to express their gratitude sincere to King Abdulalziz City for Science and Technology (KACST), Riyadh, Saudi Arabia for the valuable and continuous scientific and moral support.

\section{Authors' Contributions}

Sawsan S. Darwish, Sayed M. Ahmed, and Mohammad A. Aldosari conceived and designed the experiments; Sayed M. Ahmed and Mahmoud A. Adam performed the experiments; Sawsan S. Darwish, Nagib A. Elmarzugi, and Mahmoud A. Adam analyzed the data; Mohamed A. Aldosari and Nagib A. Elmarzugi contributed reagents/materials/analysis tools; Sawsan S. Darwish, Mahmoud A. Adam and Sayed M. Ahmed wrote and review the paper.

\section{Conflicts of Interest}

The authors have no conflicts of interest to declare.

\section{References}

[1] Vasconcelos, G. (2006) Experimental Investigations on Dry Stone Masonry Walls. 1 st International Conference on Restoration of Heritage Masonry Structures, Cairo, 24-27 April 2006, 214-223.

[2] Fitzner, B., Heinrichs, K. and Bouchardiers, D. (2002) Limestone Weathering of Historical Monuments in Cairo, Egypt. Special Publication, Geological Society of London, London, Volume 205, 217-239. https://doi.org/10.1144/GSL.SP.2002.205.01.17

[3] May, C.A. (1988) Epoxy Resins, Chemistry and Technology. Second Edition, Marcel Dekker, New York, Basel.

[4] Petrie, E.M. (2006) Epoxy Adhesive Formulations. McGraw-Hill, New York.

[5] Rodgers, R.M., Mahfuz, H., Rangari, V.K., Chisholm, N. and Jeelani, S. (2005) Infusion of SiC Nanoparticles into SC-15 Epoxy: An Investigation of Thermal and Mechanical Response. Macromolecular Materials and Engineering, 290, 423-429. https://doi.org/10.1002/mame.200400202 
[6] Cavaletti, R., Lazzarini, L., Marchesini, L. and Marinelli, G. (1985) A New Type of Epoxy Resin for the Structural Consolidation of Badly Decayed Stones. 5th International Congress on the Deterioration and Conservation of Stone, Lausanne, 25-27 September 1985, 769-777.

[7] Bauer, R.S. (1982) Formulating Weatherable Epoxy Resin for Maximum Performance. Water Borne and Higher Solids Coatings Symposium, New Orleans, 1982, 729-783.

[8] Dillard, D. (2010) Improvements in Structural Adhesive Bonding. Woodhead Publishing Ltd., Cambridge. https://doi.org/10.1533/9781845698058

[9] Domaslowski, W. and Strzelczyk, A. (1986) Evaluation of Applicability of Epoxy Resins to Conservation of Stone Historic Monuments. Case Studies in the Conservation of Stone and Wall Painting. Preprints of the Contributions to the Bologna Congress, London, 22-26 September 1986, 126-132.

https://doi.org/10.1179/sic.1986.31.Supplement-1.126

[10] Proudfoot, T., Garland, K. and Larsen, J. (1988) The Examination and Conservation of a Collection of Gandharan Sculptures from Antony House, Cornwall. The Conservation of Far Eastern Art, IIC, Kyoto, 19-23 September 1988, 113-120. https://doi.org/10.1179/sic.1988.33.1.113

[11] Kinloch, A.J. (2003) Toughening Epoxy Adhesives to Meet Today's Challenges. MRS Bulletin, 28, 445-448. https://doi.org/10.1557/mrs2003.126

[12] Podany, J., Garland, K., Freeman, W. and Rogers, J. (2000) Paraloid B-72 as a Structural Adhesive and as a Barrier within Structural Adhesive Bonds: Evaluations of Strength and Reversibility. Journal of the American Institute for Conservation, 40, 15-33. https://doi.org/10.1179/019713601806113120

[13] Khashaba, U.A., Aljinaidi, A.A. and Hamed, M.A. (2014) Nanofillers Modification of Epocast 50-A1/946 Epoxy for Bonded Joints. Chinese Journal of Aeronautics, 27, 1288-1300. https://doi.org/10.1016/j.cja.2014.08.007

[14] Kavitha, N., Balasubramanian and Kennedy, A.X. (2013) Investigation of Impact Behavior of Epoxy Reinforced with Nanometer- and Micrometer-Sized Silicon Carbide Particles. Journal of Composite Materials, 47, 1877-1884. https://doi.org/10.1177/0021998312451920

[15] Faleh, H., Al-Mahaidi, R. and Shen, L. (2012) Fabrication and Characterization of Nano-Particles-Enhanced Epoxy. Composites Part B: Engineering, 43, 3076-3080. https://doi.org/10.1016/j.compositesb.2012.04.055

[16] Dorigato, A. and Pegoretti, A. (2012) Development and Thermo-Mechanical Behaviour of Nanocomposite Epoxy Adhesives. Polymers for Advanced Technologies, 23, 660-668. https://doi.org/10.1002/pat.1942

[17] Prolongo, S.G., Gude, M.R., Sanchez, J. and Urena, A. (2009) Nanoreinforced Epoxy Adhesives for Aerospace Industry. The Journal of Adhesion, 85, 180-199. https://doi.org/10.1080/00218460902881766

[18] Pinto, D., Bernardo, L., Amaro, A. and Lopes, S. (2015) Mechanical Properties of Epoxy Nanocomposites Using Titanium Dioxide as Reinforcement-A Review. Construction and Building Materials, 95, 506-524.

[19] Hussain, F., Hojjati, M., Okamoto, M. and Gorga, R.E. (2006) Review Article: Polymer-Matrix Nanocomposites, Processing, Manufacturing, and Application: An Overview. Journal of Composite Materials, 40, 1511-1575. https://doi.org/10.1177/0021998306067321

[20] Becker, O. and Simon, G.P. (2005) Epoxy Layered Silicate Nanocomposites. Advances in Polymer Science, 179, 29-82. https://doi.org/10.1007/b107204 
[21] Karamipour, S., Ebadi-Dehaghani, H., Ashouri, D. and Mousavian, S. (2011) Effect of Nano- $\mathrm{CaCO}_{3}$ on Rheological and Dynamic Mechanical Properties of Polypropylene: Experiments and Models. Polymer Testing, 30, 110-117. https://doi.org/10.1016/j.polymertesting.2010.10.009

[22] Liu, W., Hoa, S.V. and Pugh, M. (2005) Organoclay-Modified High Performance Epoxy Nanocomposites. Composite Science and Technology, 65, 307-316. https://doi.org/10.1016/j.compscitech.2004.07.012

[23] Jan, I.-N., Lee, T.M., Chiou, K.C. and Lin, J.J. (2005) Comparisons of Physical Properties of Intercalated and Exfoliated Clay/Epoxy Nanocomposites. Industrial \& Engineering Chemistry Research, 44, 2086-2090. https://doi.org/10.1021/ie048934+

[24] Zaman, I., et al. (2015) Influence of Interface on Epoxy/Clay Nanocomposites: 1. Morphology Structure. Procedia Manufacturing, 2, 17-22.

https://doi.org/10.1016/j.promfg.2015.07.004

[25] Shentu, B., Li, J. and Weng, Z. (2006) Effect of Oleic Acid-Modified Nano-CaCO on the Crystallization Behavior and Mechanical Properties of Polypropylene. Chinese Journal of Chemical Engineering, 14, 814-818. https://doi.org/10.1016/S1004-9541(07)60018-4

[26] Saghi, S.S., Zebarjad, S.M., Khaki, J.V. and Sajjadi, S.A. (2009) The Effect of Nano-Sized Calcium Carbonate on Thermodynamic Parameters of HDPE. Journal of Materials Processing Technology, 209, 1310-1317. https://doi.org/10.1016/j.jmatprotec.2008.03.066

[27] Zhang, Z., Wang, C., Meng, Y. and Mai, K. (2012) Synergistic Effects of Toughening of $\mathrm{Nano}_{-} \mathrm{CaCO}_{3}$ and Toughness of $\beta$-Polypropylene. Composites Part A: Applied Science and Manufacturing, 43, 189-197. https://doi.org/10.1016/j.compositesa.2011.10.008

[28] Maravelaki-Kalaitzaki, P., Kallithrakas-Kontos, N., Agioutantis, Z., Maurigiannakis, S. and Korakaki, D. (2008) A Comparative Study of Porous Limestones Treated with Silicon-Based Strengthening Agents. Progress in Organic Coatings, 62, 49-60. https://doi.org/10.1016/j.porgcoat.2007.09.020

[29] Ren, C., Sun, J., Li, J., Chen, X., Hu, Z. and Xue, D. (2009) Bi-Functional Silica Nanoparticles Doped with Iron Oxide and CdTe Prepared by a Facile Method. Nanoscale Research Letters, 4, 640-645. https://doi.org/10.1007/s11671-009-9295-9

[30] Xue, L., Li, J., Fu, J. and Han, Y. (2009) Super-Hydrophobicity of Silica Nanoparticles Modified with Vynil Groups. Colloid Surface A, 338, 15-19. https://doi.org/10.1016/j.colsurfa.2008.12.016

[31] Aldoasri, M.A., Darwish, S.S., Adam, M.A., Elmarzugi, N.A. and Ahmed, S.M. (2017) Enhancing the Durability of Calcareous Stone Monuments of Ancient Egypt Using $\mathrm{CaCO}_{3}$ Nanoparticles. Sustainability, 9, 1-17. https://doi.org/10.3390/su9081392

[32] Buasri, A., Chaiyut, N., Borvornchettanuwat, K., Chantanachai, N. and Thonglor, K. (2012) Thermal and Mechanical Properties of Modified $\mathrm{CaCO}_{3} / \mathrm{PP}$ Nanocomposites. International Journal of Chemical, Molecular, Nuclear, Materials and Metallurgical Engineering, 6, 689-692.

[33] Bagherzadeh, M.R. and Mahdavi, F. (2007) Preparation of Epoxy-Clay Nanocomposite and Investigation on Its Anti-Corrosive Behavior in Epoxy Coating. Progress in Organic Coatings, 60, 117-120. https://doi.org/10.1016/j.porgcoat.2007.07.011

[34] BS EN 12370 (1999) Natural Stone Test Methods-Determination of Resistance to Salt Crystallisation.

[35] Khallaf, M.K., El-Midany, A.A. and El-Mofty, S.E. (2011) Influence of Acrylic 
Coatings on the Interfacial, Physical, and Mechanical Properties of Stone-Based Monuments. Progress in Organic Coatings, 72, 592-598.

https://doi.org/10.1016/j.porgcoat.2011.06.021

[36] ASTM D 412-66 T (1998) Standard Test Method for Tensile Strength and Young's Modulus for High-Modulus Single-Filament Materials.

[37] ASTM C (1976) American Society for Testing, and Protection of Stone Monuments. Standard Test Methods for Compressive Strength of Natural Building Stone, ASTM C 170, UNESCO, Paris.

[38] Bashar, M.T. and Mertiny, P. (2014) Mechanical and Mode-I Fracture Properties of Epoxy-Clay Nanocomposites Prepared by Ultrasonic Dispersion Method. International Journal of Materials Science and Engineering, 2, 87-92.

[39] Kusmono, Wildan, M.W. and Mohd Ishak, Z.A. (2013) Preparation and Properties of Clay-Reinforced Epoxy Nanocomposites. International Journal of Polymer Science, 2013, Article ID: 690675. https://doi.org/10.1155/2013/690675

[40] Tjong, S.C. (2006) Structural and Mechanical Properties of Polymer Nanocomposites. Materials Science and Engineering $R, 53,73-197$.

https://doi.org/10.1016/j.mser.2006.06.001

[41] Eiras, D. and Pessan, L.A. (2009) Mechanical Properties of Polypropylene/Calcium Carbonate Nanocomposites. Materials Research, 12, 517-522.

https://doi.org/10.1590/S1516-14392009000400023 